\title{
The Application of Problem Solving Reasoning (PSR) in Improving Students' Metacognitive at the Twelfth Grade Students of SMAN 19 Makassar
}

\author{
Sujarwo ${ }^{1, a^{*}}$, Akhiruddin ${ }^{1, b}$, Muh. Reski Salemuddin $1, c$, Bellona Mardhatillah Sabillah 1,d, Sriwahyuni1,e \\ 1 Universitas Megarezky, Jl. Antang Raya No.45, Makassar, 90234, Indonesia. \\ a jarwo.ibrahim@gmail.com; b akhiruddin114@gmail.com; c muhrezkysalemuddin@ymail.com; d bellona.sabillah@yahoo.com; e sriwahyunitiro@gmail.com \\ *Corresponding Author \\ Whatsapp Number: [+62-81230091927]
}

How to Cite : Sujarwo, S., Akhiruddin, A., Salemuddin, M., R., Sabillah, B., M. \& Sriwahyuni, S. (2019). The Application of Problem Solving Reasoning (PSR) in Improving Students' Metacognitive at the Twelfth Grade Students of SMAN 19 Makassar. International Journal for Educational and Vocational Studies, 1 (2), $138-141$.

\section{ARTICLE HISTORY}

Received:3 March 2019

Revised: 23 April2019

Accepted: 26 May 2019

\section{KEYWORDS}

Problem Solving Reasoning;

Students' Metacognitive;

\begin{abstract}
The study describes the students' thinking skill, and metacognitive in problem solving reasoning (PSR) learning model at SMAN 19 Makassar in the academic year 2018/2019. The design of this research was Classroom Action Research (CAR) in which subject was students social science eleventh grade students that consisted of 69 students. Data were collected by using a problem-solving reasoning tests in the form of multiple choice, essay, oral and practice tests. Data of problem solving reasoning (PSR) abilities were analyzed quantitatively and qualitatively. The results of this study show that: (1) The application of problem solving reasoning (PSR) can improve the statistical students' metacognitive of social science eleventh grade students. In cycle I, the students' English outcomes average reached 59.2, whereas in cycle II was successfully increased into 84.8, In cycle I, the students' sociology and anthropology outcomes average reached 60.9 , whereas in cycle II was successfully increased into 88.5 and in cycle I, the students' Art and Culture outcomes average reached 62.3, whereas in cycle II was successfully increased into 86.9. (2) The application of problem solving reasoning (PSR) can improve students' metacognitive of social science XI grade students. These results indicate that there has been an increasing in percentage mastery learning by $20 \%$ from cycle I to cycle II.
\end{abstract}

This is an open access article under the CC-BY-SA license.

\section{INTRODUCTION}

Students' activity in building their own knowledge is a priority in science learning. They are expected to be more independent in constructing their knowledge during the learning process. In the process of constructing such as knowledge, students are required to be able to compare the prior knowledge with the new knowledge that they have acquired. Metacognitive plays an important role in this process (Adhitama, et al, 2014; and Ramadani, et al, 2015). Metacognitive is knowledge and beliefs about cognitive processes of a person and his conscious efforts to engage in the process of behaving and thinking (Munir, 2016; Scott, 2015) about thinking itself (Nasution \& Rezeqi, 2015). There are two components of metacognitive: knowledge and regulation. Metacognitive knowledge includes knowledge of their position as learning and the factors that influence his achievement, knowledge of strategy, and knowledge of what and why to use the strategy. Metacognitive regulation includes the process of monitoring cognition, such as planning activities and evaluating the efficacy of monitoring processes and strategies (Jeronenet et al, 2016; and Tanner, 2012).

While Problem Solving Reasoning (PSR) is a problem solving learning that is learning that focuses on teaching and problem-solving skills followed by strengthening of skills through hands-on learning experiences equipped with steps to support reasoning ability include: (1) basic thinking; (2) critical thinking; and (3) creative thinking. Reasoning encompasses the cognitive procedures we use to make inferences from knowledge and draw conclusions (Dunbar K, and Fugelsang, J, 2006). Reasoning is a part of thinking that is above the level of retention or recall, reasoning includes: basic thinking, critical thinking, and creative thinking (Sanjaya, W, 2006). The problem-solving learning model is a learning model that focuses on teaching and problem-solving skills followed by skill enhancement (Shoimin A, 2014). Problem solving is one of 
the problem-based teaching strategies where teachers help learners to learn to solve problems through hands-on learning experiences (Jacobsen D A, et al, 2009). Hands-on learning is a learning that requires active learners to solve problems. Based on the description above, the study explored about how the implementation of Problem Solving Reasoning (PSR) on metacognitive students.

Problem solving reasoning has the phases, they are: read and think, explore and plan, select a strategy, find and answer, reflect and extend, and the principle of reaction that students have been trained to develop their reasoning power in solving problems that will later increase their ability to think critically and creatively. The learning process of problem solving reasoning learning model and it is not oriented to the final answer to a problem presented, but rather how the answer is obtained. The problems given are problems that are able to provide opportunities for students to give answers according to their wishes for reasons that are responsibility by students.

\section{METHODS}

This research is a Classroom Action Research (CAR) which is intended to make a contribution to the improvement of teachers' knowledge, style, model, technique and method in the classroom, and to give insight into the behaviour of both teachers and students in applying the problem solving reasoning (PSR).

The scheme of Classroom Action Research

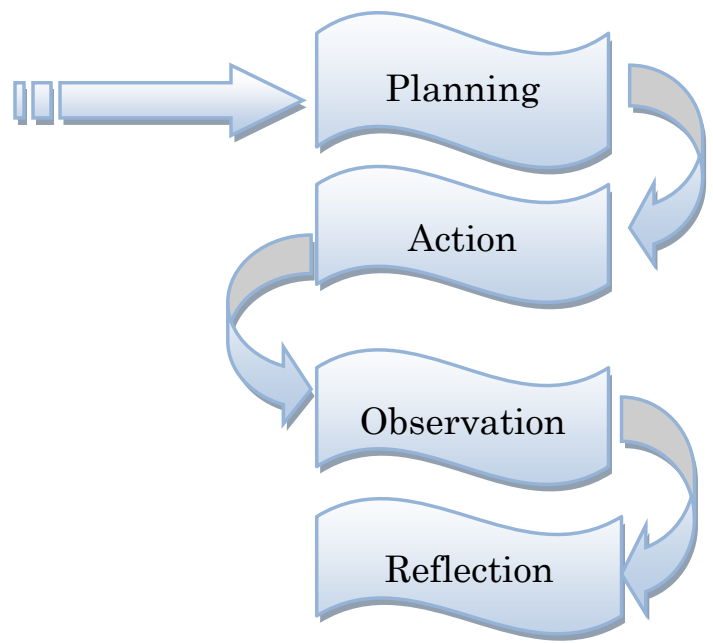

Fig. 1. Scheme of Classroom Action Research

The research was conducted at social science XI grade students of SMAN 19 Makassar. The numbers of students were 69 students, it was consisted from two classes, and they were XI-1 and XI-2 of Social Science classes. It used an action research design in order to answer the research problem. In addition, the primary aim of the research is to improve the quality of teaching and learning of students' metacognitive. This study tries to describe the implementation of problem solving reasoning (PSR) to provide an improved way for teachers to teach. This CAR employs a collaborative research design. The researchers and their collaborative classroom directly conducted the study. To cope with the problems found in the classroom in teaching English, Sociology Anthropology and Art and Culture subjects. The researchers applied problem solving reasoning (PSR) during the teaching and learning process. Here, the researchers acted as the practitioners who taught the students with problem solving reasoning (PSR) through their metacognitive in learning Sociology Anthropology and Art and Culture subjects. Sources of data to get the data about the improvement in the students' metacognitive, the researchers used data from the results of the students" tests in two cycles namely cycle one and cycle two. Further, to observe the data of the students" response toward the process of learning by using problem solving reasoning (PSR), the researchers got the data using test. In this study, the researchers used data (1) from observing the students" activities, (2) from the interviews between the researchers and the students, (3) from the tests (multiple choice, essay, oral and practice) and also (4) from the students" answers from each tests that conducted at the end of each cycle during problem solving reasoning (PSR) implementation in the teaching and learning activities.

\section{RESULTS AND DISCUSSION}

The researcher showed analysis for each subject that conducted at SMAN 19 Makassar.

\section{Sociology Anthropology}

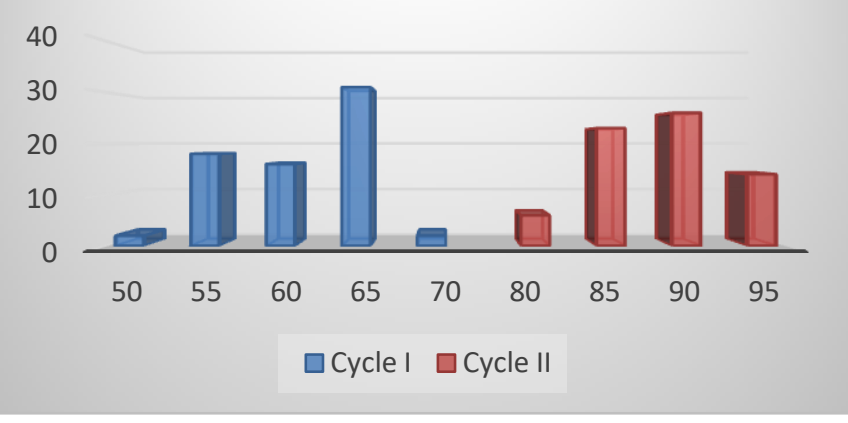

Fig. 2. Diagram of students' Sociology and Athropology outcomes

As described in figure 2 above showed that students got score of 50 categorized as fair in cycle I. Then 18 students achieved score of 55 that categorized as fair. Next, 16 students got score of 60 that categorized as fair and 2 students go score of 70 categorized as good. For cycle II, there were 6 students who achieved score of 80 that categorized as good. Next, 23 students got 85 that categorized as very well. Then, 26 students got score of 90 that categorized as very well. Last, 14 students got score of 95 that categorized as very well. It meant that there was 
improvement from score of 55 as small score in cycle I to score of 80 as small one in cycle II. Furthermore, mean score of students' Sociology and Anthropology outcomes was 60.9 for cycle I, while mean score of students' Sociology and Anthropology outcomes was 88.5 for cycle II.

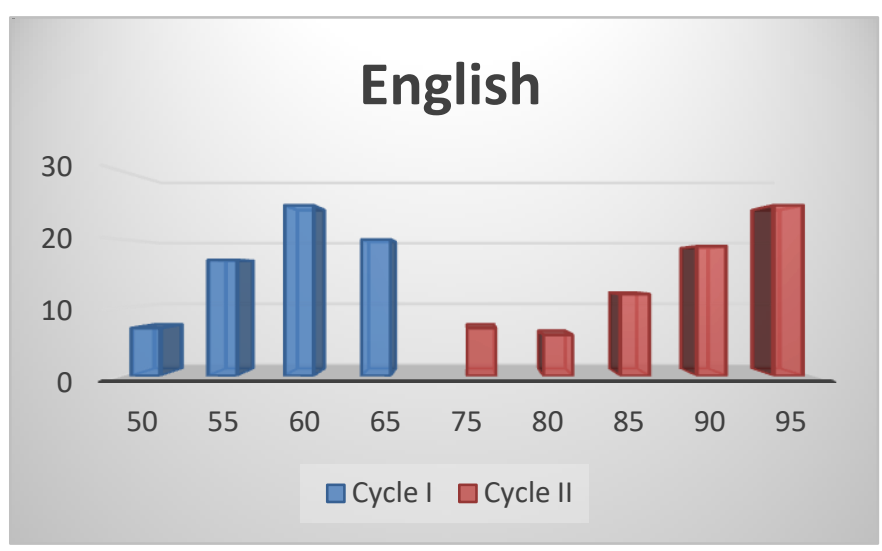

Fig. 3. Diagram of students' English outcomes

As described in figure 3 above showed that students got score of 50 categorized as fair in cycle I. Then 18 students achieved score of 55 that categorized as fair. Next, 16 students got score of 60 that categorized as fair and 2 students go score of 70 categorized as good. For cycle II, there were 6 students who achieved score of 80 that categorized as good. Next, 23 students got 85 that categorized as very well. Then, 26 students got score of 90 that categorized as very well. Last, 14 students got score of 95 that categorized as very well. It meant that there was improvement from score of 55 as small score in cycle I to score of 80 as small one in cycle II. Furthermore, mean score of students' English outcomes was 59.2 for cycle I, while mean score of students' English outcomes was 84.8 for cycle II.

\section{Art and Culture}

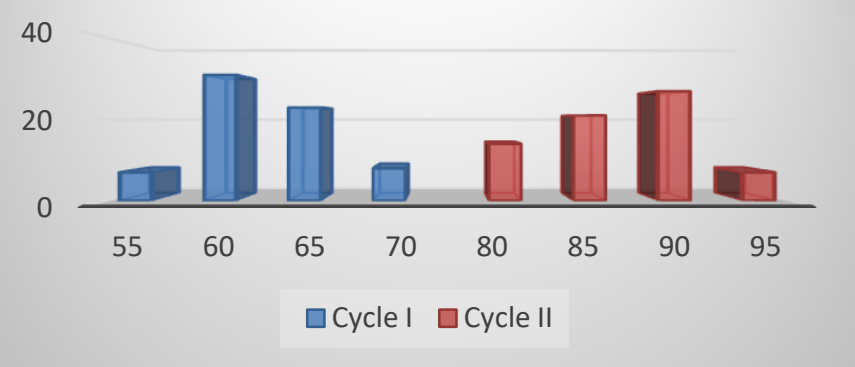

Fig. 4. Diagram of students' Art and Culture Outcomes

As described in figure 4 above showed that students got score of 50 categorized as fair in cycle I. Then 18 students achieved score of 55 that categorized as fair. Next, 16 students got score of 60 that categorized as fair and 2 students go score of 70 categorized as good. For cycle II, there were 6 students who achieved score of 80 that categorized as good. Next, 23 students got 85 that categorized as very well. Then, 26 students got score of 90 that categorized as very well. Last, 14 students got score of
95 that categorized as very well. It meant that there was improvement from score of 55 as small score in cycle I to score of 80 as small one in cycle II. Furthermore, mean score of students' art and culture outcomes was 62.3 for cycle I, while mean score of students' Art and Culture outcomes was 86.9 for cycle II.

Based on the data analysis, the reserchers found that metacognitive can not come suddenly. The students have to be divided into some groups to create cooperative learning. By this way, the students can stimulate their thinking to use prior knowledge, plan a strategy, monitor their thinking dan modify their thinking so that the students can build their creative thinking to find solution of problem.

As described by Jeronenet et al, (2016) and Tanner, (2012) metacognitive function consisted of metacognitive awareness, metacognitive evaluation and metacognitive regulation. The researchers found that students can improve their metacognitive by using metacognitive knowledge and metacognitive regulation to problem solving reasoning, especially in answering assigment given by teachers.

\section{CONCLUSION}

Based on the result of the research, it can be concluded that the application of problem solving reasoning (PSR) can improve students' metacognitive statistics learning mastery social science XI grade students. It is proved by mean score for each subject improving. For Sociology and Antropology mean score of students' Sociology and Anthropology outcomes was 60.9 for cycle I, while mean score of students' Sociology and Anthropology outcomes was 88.5 for cycle II. Then in English, mean score of students' English outcomes was 59.2 for cycle I, while mean score of students' English outcomes was 84.8 for cycle II. Last in Art and Culture mean score of students' Sociology and Anthropology outcomes was 62.3 for cycle I, while mean score of students' Art and Culture outcomes was 86.9 for cycle II. Hese results indicate that there has been an increasing in percentage mastery learning by $20 \%$ from cycle I to cycle II.

\section{REFERENCES}

Adhitama, R. S., Kusnadi, K., \& Supriatno, B. (2014). Kesadaran metakognitif siswa dalam pembelajaran berbasis proyek pada pokok bahasan pencemaran lingkungan. Asimilasi, I(1), 2-11.

Arikunto, et al. (2006). Classroom Action Research. Jakarta: Bumi Aksara

Dunbar K, and Fugelsang J 2006 Problem Solving and Reasoning Appear in E.E. Smith \& S.Kosslyn an introduction to cognitive psychology http://www.utsc.utoronto.ca/

Foshay, R. \& Kirkley, J. (2003). Principles for Teaching 
Problem Solving. Tersedia: www.plato.com/downloads /papers/paper_04.pdf diakses tanggal 15 December 2018.

Harrison, G. M., \& Vallin, L. M. (2017). Evaluating the metacognitive awareness inventory using empirical factor-structure evidence.Metacognition and Learning, 1- 25. https://doi.org/10.1007/s11409-017-9176-z

Jacobsen D A, Eggen P, and Kauchak D 2009 Methods for Teaching (Terj A Fawaid \& C. Anam.Yogyakarta: Pustaka Pelajar)

Jagals, D., \& Walt, M. Van Der. (2016). Enabling metacognitive skills for mathematics problem solving: A collective case study of metacognitive reflection and awareness. African Journal of Research in Mathematics, Science and Technology Education, 20(2), 154-164.

https://doi.org/10.1080/18117295.2016.1192239

Kallio, H., Virta, K., \& Kallio, M. (2018). Modelling the components of metacognitive awareness.

International Journal of Educational Psychology, 7(2),94-122. https://doi.org/10.17583/ijep.2018.2789

Kunandar. (2011). Langkah Mudah Penelitian Tindakan Kelas. Jakarta: PT. Rajawali Pers.

Munir, N. P. (2016). Pengaruh kesadaran metakognitif terhadap motivasi belajar dan kaitannya dengan hasil belajarn matematika siswa kelas XI SMA Negeri di Kota Pare-Pare. Al-Khwarizmi: Jurnal Pendidikan Matematika dan Ilmu Pengetahuan ALam, 4(2), 117-128

Murni. (2013). Open-Ended Approach in Learning to Improve Students Thinking Skills in Banda Aceh.International Jurnal of Independent Research and studies-IJIRS. Vol. 2, No. 2 (April, 2013) 95-101.

Nasution, M. Y., \& Rezeqi, S. (2015). Application of contextual learning to improve critical thinking ability of students in biology teaching and learning strategies class. International Journal ofLearning, Teaching and Educational Research, 11(3), 109-116

Sanjaya, W. (2006). Strategi Pembelajaran Berorientasi Standar Proses Pendidikan (Jakarta:Kencana)

Santyasa. I. W. (2005). Model Pembelajaran Inovatif Dalam Implementasi Kurikulum. Tersedia pada: http://www.freewebs.com diakses pada tanggal 5 January 2019.

Shoimin, A. (2014). 68 Model Pembelajaran Inovatif dalam Kurikulum 2013 (Yogyakarta: Ar-ruzz Media)

Sugiyono. (2008). Metode Penelitian Kuantitatif Kualitatif dan $R$ \& amp; D. Bandung: Alfabeta

Tanner, K. D. (2012). Promoting student metacognition. CBE Life Sciences Education, 11(2), 113-120. https://doi.org/10.1187/cbe.12-03-0033 